Article

\title{
Producing of cinnamyl alcohol from cinnamaldehyde over supported gold nanocatalyst
}

\author{
Yuan Tan a,b, Xiaoyan Liu a,*, Leilei Zhang a, Fei Liu a , Aiqin Wang a, Tao Zhang a,c \\ a CAS Key Laboratory of Science and Technology on Applied Catalysis, Dalian Institute of Chemical Physics, Chinese Academy of Sciences, Dalian 116023, \\ Liaoning, China \\ b Zhejiang Normal University, Hangzhou Institute of Advanced Studies, Hangzhou 311231, Zhejiang, China \\ c University of Chinese Academy of Sciences, Beijing 100049, China
}

\section{A R T I C L E I N F O}

\section{Article history:}

Received 19 May 2020

Accepted 23 June 2020

Published 5 March 2021

\section{Keywords:}

Gold nanocluster

Support effect

Cinnamyl alcohol

Selective hydrogenation

Cinnamaldehyde

\begin{abstract}
A B S T R A C T
Chemoselective hydrogenation of unsaturated aldehyde to unsaturated alcohol has attracted growing interests in recent years due to its widespread applications in fine chemicals. However, the hydrogenation of the $\mathrm{C}=\mathrm{O}$ bond was thermodynamically and kinetically unfavorable over the hydrogenation of the $\mathrm{C}=\mathrm{C}$ bond. Thus, to obtain the unsaturated alcohol from the unsaturated aldehyde is very difficult in most of the catalytic systems. In this work, ZnAl-hydrotalcite-supported cysteine-capped $\mathrm{Au}_{25}$ nanoclusters were used as the precatalysts for chemoselective hydrogenation of cinnamaldehyde to cinnamyl alcohol. The catalyst showed stable high selectivity $(\sim 95 \%)$ at prolonged reaction time and complete conversion of the substrate. According to the results of the control experiments, the in-situ DRIFTS of the substrate under high pressure of hydrogen and the ${ }^{27} \mathrm{Al}$ MAS-NMR spectroscopy, we proposed that the difference of the preferential adsorption of the $\mathrm{C}=\mathrm{O}$ bond to that of the $\mathrm{C}=\mathrm{C}$ bond was derived from the nature of the support of the gold catalysts.
\end{abstract}

(C) 2021, Dalian Institute of Chemical Physics, Chinese Academy of Sciences. Published by Elsevier B.V. All rights reserved.

\section{Introduction}

The selective hydrogenation of $\alpha, \beta$-unsaturated ketones and aldehydes to the corresponding unsaturated alcohols was among one of the most important industrial reactions $[1,2]$. The unsaturated alcohols were considered as the key intermediates in the synthesis of fine chemicals, fragrances, pharmaceuticals, agrichemicals and cosmetics [3]. In traditional industrial process, the selective reductions of unsaturated ketones and aldehydes could be achieved by using stoichiometric reducing agent such as the sodium borohydride [2,4]. However, this method involved harmful inorganic reagent even with high selectivity, which was not environmentally friendly. Thus, it is desirable to search for green synthesis routes for synthesis of unsaturated alcohols.

Nevertheless, it was difficult to obtain the unsaturated alcohols from unsaturated ketones and aldehydes with high selectivity, due to the competition between the unsaturated groups reacting with the hydrogen molecule. Cinnamaldehyde (CAL) is a representative substrate containing the carbonyl and vinyl groups simultaneously. As illustrated in Scheme 1, the partial hydrogenation of CAL led to the formation of cinnamyl alcohol (COL) and hydrocinnamaldehyde (HCAL), when the $\mathrm{C}=\mathrm{O}$ and the $\mathrm{C}=\mathrm{C}$ groups were hydrogenated, respectively. Actually, it was one of the most challenging subjects to obtain the COL, since the hydrogenation of the $\mathrm{C}=\mathrm{O}$ bond was thermody-

\footnotetext{
* Corresponding author. Tel: +86-411-84379416; Fax: +86-411-84691570; E-mail: xyliu2003@dicp.ac.cn

This work was supported by the National Natural Science Foundation of China (21776271, 21606227), the National Key Research \& Development Program of China (2016YFA0202801), the Strategic Priority Research Program of the Chinese Academy of Sciences (XDB17020100), Zhejiang Provincial Natural Science Foundation of China (LQ20B030005), and CAS Interdisciplinary Innovation Team (BK2018001).

DOI: 10.1016/S1872-2067(20)63678-6 | http://www.sciencedirect.com/science/journal/18722067 | Chin. J. Catal., Vol. 42, No. 3, March 2021
} 


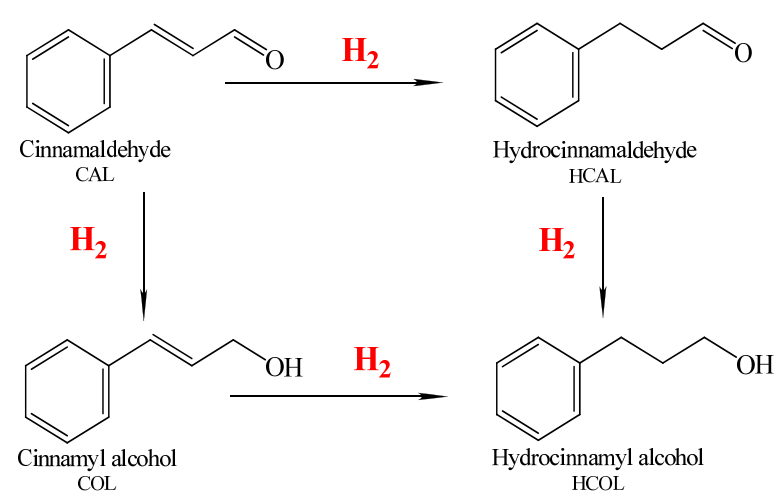

Scheme 1. Reaction pathways of hydrogenation of cinnamaldehyde.

namically and kinetically unfavorable over the hydrogenation of the $\mathrm{C}=\mathrm{C}$ bond $[1,2,5]$. On the traditional precious metal catalysts (e.g., Pt, Pd, Ru, Rh etc.), producing HCAL and hydrocinnamyl alcohol (HCOL) were always easier than COL due to their strong dissociation ability of the hydrogen and relatively easier activation of the $\mathrm{C}=\mathrm{C}$ bond [6-9].

Supported gold nanoparticles (NPs) have attracted intensive attentions recently because of their high selectivity in various redox reactions under moderate reaction conditions [10-12]. In previous works, the gold catalysts exhibited potential high selectivity in the selective hydrogenation of unsaturated ketones and aldehydes, which is comparatively superior to other supported noble metal catalysts $[13,14]$. The performances of the gold catalysts were largely affected by the steric and electronic effects [15-17] caused by the size and morphology of gold particles [18-20] and the addictive elements [21-23]. What's more, the activation of the $\mathrm{C}=\mathrm{C}$ bond and the $\mathrm{C}=\mathrm{O}$ bond is also competitive over most of the supported gold catalysts $[19,24]$. Thus, to get a stable high selectivity of unsaturated alcohol on supported gold catalysts especially in high conversions confront with enormous challenges.

Previously, we designed a gold catalyst by utilizing ZnAl-hydrotalcite (HT) supported $\mathrm{Au}_{25}$ nanoclusters (NCs) as the precatalyst for chemoselective hydrogenation of nitrostyrene to aminostryene [25]. Notably, it showed high selectivity for hydrogenation of $-\mathrm{NO}_{2}$ group, while displaying almost inert activity for $\mathrm{C}=\mathrm{C}$ group. Considering the commonness, herein, we applied this catalyst $\left(\mathrm{Au}_{25} / \mathrm{ZnAl}-300\right)$ to the selective hydrogenation of CAL to COL, which is much more competitive between the $-\mathrm{C}=\mathrm{O}$ and the $-\mathrm{C}=\mathrm{C}$ than the $-\mathrm{NO}_{2}$ and the $-\mathrm{C}=\mathrm{C}$. We found a stable high selectivity produced on this catalyst: even in the prolonged reaction time, the selectivity of COL could be preserved at above $95 \%$ in complete conversion of CAL. This result was unprecedented through the previously developed supported gold catalysts. The reaction route was investigated based on the dynamic test, control experiment (e.g., using styrene and the mixture of styrene and benzaldehyde as the substrate, changing the solvent, etc.) and in-situ DRIFTS of CAL adsorption and reaction under high pressure of hydrogen.

\section{Experimental}

\subsection{Chemicals}

All chemicals were used as received and without any purification. All glassware were washed with Aqua Regia $\left(V_{\mathrm{HCl}}: V_{\mathrm{HNO3}}=3: 1\right)$ and rinsed with ethanol and ultrapure water. Ultrapure water (18.2 $\mathrm{M} \Omega$ ) was used throughout this work.

Hydrogen tetrachloroaurate (III) hydrate $\left(\mathrm{HAuCl}_{4} \cdot 3 \mathrm{H}_{2} \mathrm{O}\right)$ was from Sinopharm Chemical Reagent (Beijing Co. Ltd.). Cysteine (Cys) was purchased from Sigma-Aldrich. Zinc nitrate hydrate $\left(\mathrm{Zn}\left(\mathrm{NO}_{3}\right)_{2} \cdot 6 \mathrm{H}_{2} \mathrm{O}\right)$, Magnesium nitrate hydrate $\left(\mathrm{Mg}\left(\mathrm{NO}_{3}\right)_{2} \cdot 6 \mathrm{H}_{2} \mathrm{O}\right)$, Nickel nitrate hydrate $\left(\mathrm{Ni}\left(\mathrm{NO}_{3}\right)_{2} \cdot 6 \mathrm{H}_{2} \mathrm{O}\right)$, Aluminium nitrate hydrate $\left(\mathrm{Al}\left(\mathrm{NO}_{3}\right)_{3} \cdot 9 \mathrm{H}_{2} \mathrm{O}\right)$, were purchased from Tianjin Damao Chemical Reagent Factory. Sodium borohydride $\left(\mathrm{NaBH}_{4}\right)$, sodium carbonate, sodium hydroxide $(\mathrm{NaOH})$, were purchased from Tianjin Tianli Chemical Reagent Ltd. The cinnamaldehyde, cinnamyl alcohol, hydrocinnamaldehyde and hydrocinnamyl alcohol used for reaction and preparation of standard line were purchased from Alfa Aesar. The solvent of isopropanol, ethyl alcohol, toluene, ethyl acetate and tetrahydrofuran were from Kermel Chemical Reagent Ltd.

\subsection{Preparation of the catalysts}

The cysteine capped NCs were prepared according to our previous work [25,26]. In a typical synthesis, aqueous solution of $\mathrm{HAuCl}_{4}(110 \mathrm{mM}, 5.00 \mathrm{~mL})$ and Cysteine solution $(5.5 \mathrm{mM}$, $150 \mathrm{~mL}$ ) were successively added into $200 \mathrm{~mL}$ of ultrapure water under gentle stirring (500 rpm). Then $30 \mathrm{~mL}$ of $1 \mathrm{M}$ $\mathrm{NaOH}$ solution was rapidly introduced into the dispersion solution. After $10 \mathrm{~min}$ of stirring, five times excessive sodium borohydride was quickly added to the above solution, and the reaction was allowed to proceed under vigorous stirring for 3 h. After the addition of $\mathrm{NaBH}_{4}$, an obvious color change from reddish brown to black brown was visible. When the reaction was finished, the products were washed thoroughly with ethanol-water $(V / V=3: 1)$ and separated by centrifugation. Then the obtained $\mathrm{Au}_{25}$ nanoclusters were dissolved in water and defined by the UV-visible spectrum. The successful synthesis of $\mathrm{Au}_{25}$ nanocluster was confirmed by the UV-vis spectrum, which showed four fingerprint peaks positioned at 440, 545, 670, and $780 \mathrm{~nm}$, respectively (Fig. 1).

The $\mathrm{ZnAl}-\mathrm{HT}(\mathrm{Zn} / \mathrm{Al}$ atomic ratio $=3$ ) support was prepared as follows: Solution A was obtained by adding $\mathrm{Zn}\left(\mathrm{NO}_{3}\right)_{2} \cdot 6 \mathrm{H}_{2} \mathrm{O}$ $(0.21 \mathrm{~mol})$ and $\mathrm{Al}\left(\mathrm{NO}_{3}\right)_{3} \cdot 9 \mathrm{H}_{2} \mathrm{O}(0.07 \mathrm{~mol})$ to $200 \mathrm{~g}$ of ultrapure water. Solution $\mathrm{B}$ was prepared by adding $\mathrm{NaOH}(0.438 \mathrm{~mol})$ and $\mathrm{Na}_{2} \mathrm{CO}_{3}(0.113 \mathrm{~mol})$ to $200 \mathrm{~g}$ of ultrapure water. After the dissolution of the powders, the solution A was slowly pumped into the solution B (velocity: $3 \mathrm{~mL} / \mathrm{min}$ ) under constant stirring in $70{ }^{\circ} \mathrm{C}$ water bath. And then additional $\mathrm{NaOH}$ solution was added to maintain the $\mathrm{pH}$ value of the suspension at 10 . The gel aged at this temperature for $24 \mathrm{~h}$. Then the mixture was filtered and washed until the $\mathrm{pH}$ value of the filtrate became neutral. The precipitate was dried in an oven at $80^{\circ} \mathrm{C}$ overnight to obtain the ZnAl-HT. The MgAl-HT and NiAl-HT supports were conducted by the same process, with the atomic ratio of $\mathrm{Mg}(\mathrm{Ni}) / \mathrm{Al}$ of 3 . 


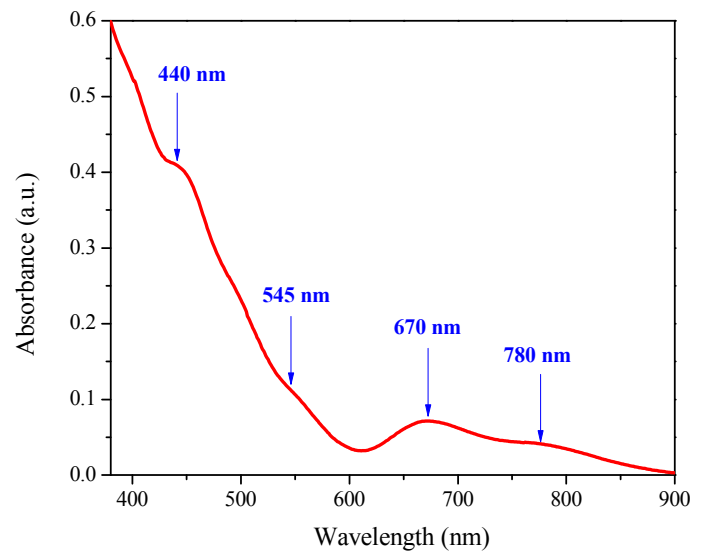

Fig. 1. UV-visible spectrum of cysteine capped $\mathrm{Au}_{25}$ nanocluster.

The HTs supported Au25 NCs was prepared by simple impregnation. In a general synthesis, $30 \mathrm{mg}$ of the $\mathrm{Au}_{25}$ nanoclusters was dispersed into $10 \mathrm{~mL}$ of ultrapure water. Then $2.00 \mathrm{~g}$ of the $\mathrm{Zn}(\mathrm{Mg} / \mathrm{Ni}) \mathrm{Al}-\mathrm{HT}$ s supports was added into the above suspension under vigorous stirring. After $1 \mathrm{~h}$, the product was washed with ultrapure water and collected by centrifugation. The residue was then dried in an oven at $80{ }^{\circ} \mathrm{C}$ for $12 \mathrm{~h}$ and calcined in muffle at $300{ }^{\circ} \mathrm{C}$ for $2 \mathrm{~h}$ with the heating rate of $5{ }^{\circ} \mathrm{C} / \mathrm{min}$. The obtained sample was defined as: Au25/ZnAl-300, Au25/MgAl-300 and Au25/NiAl-300, with the loadings of $\mathrm{Au}$ were $1.1 \mathrm{wt} \%, 1.0 \mathrm{wt} \%$, and $1.0 \mathrm{wt} \%$, respectively.

The ZnAl-HT supported gold nanoparticles (NPs) were prepared by deposition-precipitation (DP) method. In a typical synthesis, $5.2 \mathrm{~mL}$ of the aqueous solution of $\mathrm{HAuCl}_{4}(19.12$ $\mathrm{g}_{\mathrm{Au}} / \mathrm{L}$ ) was added into the suspension solution under vigorous stirring. Then $2.00 \mathrm{~g}$ ZnAl-HT powders were introduced. After that, $1 \mathrm{M} \mathrm{NaOH}$ solution was used to adjust the $\mathrm{pH}$ value to 10 . The reaction was conducted at room temperature for 12 hours. Then the solid was obtained after filtrating, washing and drying. Before the catalytic test, the solids were calcined at 300 ${ }^{\circ} \mathrm{C}$ for $2 \mathrm{~h}$, with the heating rate of $5{ }^{\circ} \mathrm{C} / \mathrm{min}$. The final loadings of $\mathrm{Au}$ were determined by the inductively coupled plasma atomic emission spectroscopy (ICP-AES), it was $1.0 \%$. The obtained sample was defined as: 1.0\% Au/ZnAl-300 (DP).

\subsection{Catalytic performance evaluation}

The liquid-phase hydrogenation of cinnamaldehyde to cinnamyl alcohol was carried out in a stainless steel autoclave equipped with a pressure gauge and magnetic stirring. Before reaction, a mixture of cinnamaldehyde $(0.05 \mathrm{M}), n$-decane $(0.025 \mathrm{M})$, solvent $(5 \mathrm{~mL})$ was put into the vessel. Then, certain amounts of catalysts were introduced into the autoclave. After being sealed, the autoclave was flushed with hydrogen for six times and then pressurized at $1.5 \mathrm{MPa}$. To initiate the reaction, the reactor was heated to $130{ }^{\circ} \mathrm{C}$ in an oil bath without stirring until the temperature reached to the specified value. That is, after the temperature reached to $130{ }^{\circ} \mathrm{C}$, the stirring was started. The stirring rate was kept at $30 \mathrm{rpm}$ till the end of the test. After the reaction, the products were condensed and analyzed by GC-MS (Varian, 450 GC, 320 MS) and GC (Agilent 7890 A) equipped with a FFAP capillary column. The control experiments were conducted in the same stainless steel autoclave under the similar reaction conditions. The substrates were replaced by the styrene and/or the artificial mixture of benzaldehyde and styrene.

\subsection{Characterization}

The actual Au loadings were measured with an inductively coupled plasma atomic emission spectroscopy (ICP-AES) on an IRIS Intrepid II XSP instrument (Thermo Electron Corporation). UV-visible spectrum was recorded on a Cintra (GBC) apparatus with water as a reference at room temperature. A continuous mode was used in the wavelength range from 200 to $900 \mathrm{~nm}$ at a scanning speed of $100 \mathrm{~nm} / \mathrm{min}$. The HAADF-STEM was recorded on a JEOL JEM-2100F microscope equipped with STEM dark-field (DF) and Oxford detectors at $200 \mathrm{kV}$. The signal of pure liquid cinnamyl aldehyde was recorded in the Bruker Vertex 70V spectrometer using the attenuated total reflection infrared (ATR-IR). The spectroscopy was equipped with a DLaTGS detector. The background spectrum was recorded at room temperature and atmospheric pressure. The liquid cinnamyl aldehyde was dropwise added onto the surface of the diamond crystal and the signal of the substrate was recorded when the liquid was evaporated. The in-situ DRIFTS of the cinnamyl aldehyde were recorded in the Bruker Vertex $70 \mathrm{~V}$ spectrometer, equipped with a MCT detector in the range of $400-4000 \mathrm{~cm}^{-1}$ with a resolution of $4 \mathrm{~cm}^{-1}$. The catalyst was packed into the sample cell with the $\mathrm{ZnSe}$ window. Before the test, the catalyst was pretreated at $120^{\circ} \mathrm{C}$ for $30 \mathrm{~min}$ to remove the absorbed water. The background spectrum was recorded under atmospheric pressure in helium, after being cooled to room temperature. Then, with the protection of helium, $\sim 5 \mu \mathrm{L}$ of the cinnamyl aldehyde was introduced into the sample for adsorption. Subsequently, $1.5 \mathrm{MPa}$ of the hydrogen was introduced into the cell using the pressure valve. After that, the reaction temperature increased to the fixed temperature with the heating rate of $10{ }^{\circ} \mathrm{C} / \mathrm{min}$. The spectra of the cinnamyl aldehyde hydrogenation process were collected at $25-180{ }^{\circ} \mathrm{C}$. For every fixed temperature, the spectrum was collected successively for twenty minutes to get the steady state. The ${ }^{27} \mathrm{Al}$ solid-state magic-angle spinning (MAS) nuclear magnetic resonance (NMR) experiments were performed on a Bruker Avance III 600 spectrometer equipped with a $14.1 \mathrm{~T}$ wide-bore magnet. The resonance frequencies in this field strength was 156.4 $\mathrm{MHz}$ for ${ }^{27} \mathrm{Al}$. The ${ }^{27} \mathrm{Al}$ spectra was recorded use a single pulse consequence with spinning rate of $10 \mathrm{kHz}$. Chemical shifts of ${ }^{27} \mathrm{Al}$ was referenced to $1.0 \mathrm{M}$ aqueous $\mathrm{Al}\left(\mathrm{NO}_{3}\right)_{3}$ solution at $0 \mathrm{ppm}$.

\section{Results and discussion}

\subsection{Catalytic performance}

To evaluate the catalytic performances of the supported 

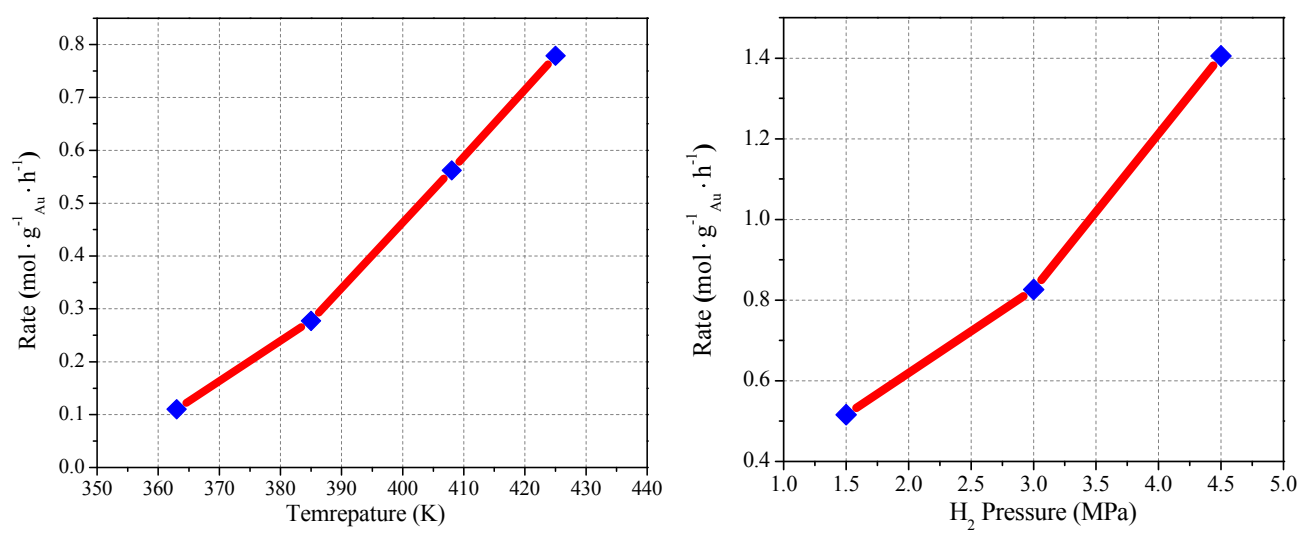

Fig. 2. The reaction rates changed as a function of the temperatures (a) and the pressures of $\mathrm{H}_{2}$ (b).

$\mathrm{Au}_{25}$ nanoclusters catalysts for selective hydrogenation of $\mathrm{CAL}$ to $\mathrm{COL}$, the influence of reaction temperature and $\mathrm{H}_{2}$-pressures were firstly studied. As displayed in Fig. 2, the reaction rates increased with the enhancement of the temperature and the hydrogen partial pressure. That meant high temperature and high hydrogen pressure were beneficial for this reaction.

Except for the above two factors, the solvent effect on the catalytic performances was also investigated. As seen from the results in Fig. 3, the reactions conducted in six different solvents rendered to different activities and selectivities under the same conditions. The best result was displayed in isopropanol and ethanol. When the two substances were used as the solvent, the selectivity of COL came close to $95 \%$ at relatively higher conversions. While the reactions were employed in other solvents such as acetate and toluene, the selectivities were far below that in isopropanol and ethanol. Previous analysis of the impact of solvent suggested that both the isopropanol and ethanol were good solvents and hydrogen donors to produce the hydrogen in the reaction process $[27,28]$. That seems to be good for the selective hydrogenation reaction.

To compare the catalytic performances of supported gold catalysts, different experiments over the supported gold

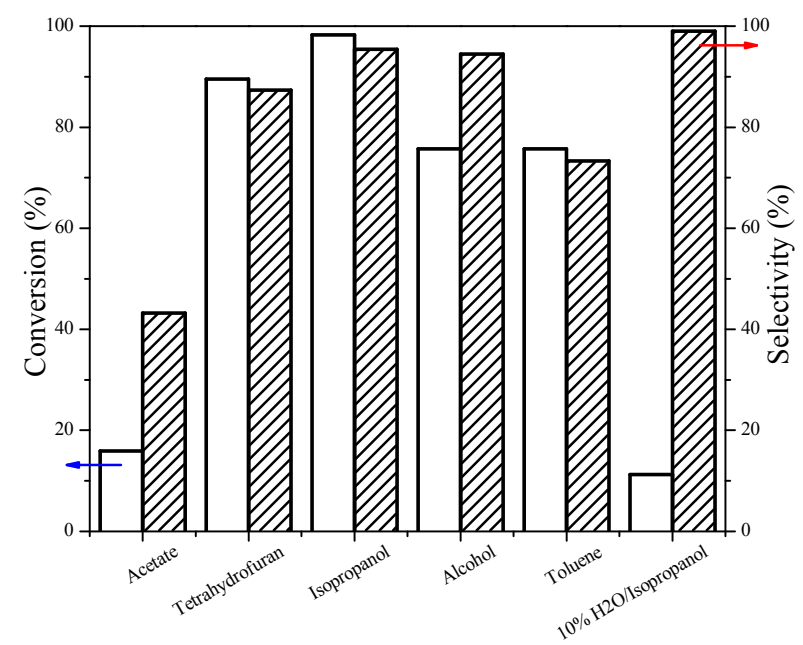

Fig. 3. The catalytic performances over the $1.0 \% \mathrm{Au}_{25} / \mathrm{ZnAl}-300$ catalyst with different solvents. Reaction conditions: cinnamaldehyde 0.25 mmol, catalyst $50 \mathrm{mg}$ (Au $1.0 \mathrm{~mol} \%$ ), $\mathrm{H}_{2}$ pressure $15 \mathrm{~atm}, 130{ }^{\circ} \mathrm{C}, 5 \mathrm{~h}$. catalysts were conducted under the same conditions. The results were displayed in Table 1 . Obviously, when using the ZnAl-HT supported $\mathrm{Au}_{25} \mathrm{NCs}$ as the precatalyst for chemoselective hydrogenation of CAL to COL, it exhibited the best performance. At this moment, the reaction conditions were performed at $130{ }^{\circ} \mathrm{C}$ and $15 \mathrm{~atm} \mathrm{H}_{2}$. The conversion and selectivity on the $\mathrm{Au}_{25} / \mathrm{ZnAl}-300$ catalyst were $98.3 \%$ and 95.4\%, respectively. In comparison, the $\mathrm{Au}_{25} / \mathrm{MgAl}-300$ and $\mathrm{Au}_{25} / \mathrm{NiAl}-300$ catalysts were synthesized with the same method as that of the $\mathrm{Au}_{25} / \mathrm{ZnAl}-300$. Both the catalysts displayed different catalytic performances, as shown in Table 1, entries 2 and 3 . Over the Au25/MgAl-300 catalyst, the conversion of CAL and the selectivity of COL were $99.2 \%$ and $39.5 \%$, respectively. Meanwhile, $13.6 \%$ of HCAL and $38.4 \%$ of HCOL were produced as the by-products. Over the $\mathrm{Au}_{25} / \mathrm{NiAl}-300$ catalysts, the results were entirely different. The CAL could not be converted to the COL. Instead, $86.7 \%$ of the HCOL was detected as the only product by chromatography analysis, which might be caused by the easy activation of hydrogen over the Ni-based supports [29].

So as to examine the effect of the gold precursor on the catalytic performance, the gold NPs synthesized by the (deposi-

Table 1

Catalytic results for the hydrogenation of CAL over the gold catalysts in this work.

\begin{tabular}{|c|c|c|c|c|c|c|}
\hline \multirow{2}{*}{ Entry } & \multirow{2}{*}{ Catalyst } & \multirow{2}{*}{$\begin{array}{l}\text { Size } \\
(\mathrm{nm})\end{array}$} & \multirow{2}{*}{$\begin{array}{c}\text { Conv. } \\
(\%)\end{array}$} & \multicolumn{3}{|c|}{ Sel. $(\%)$} \\
\hline & & & & $\mathrm{COL}$ & HCAL & HCOL \\
\hline 1 & $1.1 \% \mathrm{Au}_{25} / \mathrm{ZnAl}-300$ & $1.7 \mathrm{~b}$ & 98.3 & 95.4 & 0 & 4.5 \\
\hline 2 & $1.0 \% \mathrm{Au}_{25} / \mathrm{MgAl}-300$ & $2.2^{b}$ & 99.2 & 39.5 & 13.6 & 38.4 \\
\hline 3 & $1.0 \% \mathrm{Au}_{25} / \mathrm{NiAl}-300$ & $3.2^{b}$ & 100 & 0 & 0 & 86.7 \\
\hline 4 & $1.0 \% \mathrm{Au} / \mathrm{ZnAl}-300(\mathrm{DP})^{\mathrm{a}}$ & $2.6^{b}$ & 61.5 & 85.9 & 3.7 & 3.6 \\
\hline 5 & $1.0 \% \mathrm{Au} / \mathrm{ZrO}_{2} \mathrm{c}$ & 3.3 & 75.7 & 50.0 & 17.3 & 16.8 \\
\hline 6 & $0.8 \% \mathrm{Au} / \mathrm{Fe}_{2} \mathrm{O}_{3} \mathrm{c}$ & 1.8 & 93.0 & 45.4 & 4.9 & 3.6 \\
\hline 7 & $1.5 \% \mathrm{Au} / \mathrm{TiO}_{2}{ }^{\mathrm{d}}$ & 4.1 & 51.9 & 14.6 & 0 & 0 \\
\hline 8 & $1.1 \% \mathrm{Au}_{25} / \mathrm{ZnAl}-\mathrm{HT}$ & 1.4 & 26.8 & 43.6 & 1.6 & 0 \\
\hline 9 & ZnAl-300 & - & 9.6 & 23.9 & 3.1 & 0 \\
\hline 10 & $1.1 \% \mathrm{Au}_{25} / \mathrm{ZnAl}-300 \mathrm{e}$ & 1.7 & 28.4 & 35.2 & 0 & 0 \\
\hline
\end{tabular}

Reactions conditions: $130^{\circ} \mathrm{C}, \mathrm{H}_{2}$ pressure $15 \mathrm{~atm}$, cinnamaldehyde 0.25 mmol, solvent $5 \mathrm{~mL}$ isopropanol, $5 \mathrm{~h}$, catalyst $50 \mathrm{mg}$ (Au $1.0 \mathrm{~mol} \%$ ). a Catalysts were prepared by deposition-precipitation method; ${ }^{\mathrm{b}} \mathrm{The}$ particle sizes were the same as those in Ref. [26]; ' Catalysts were provided by Haruta Gold Incorporated Company; ${ }^{\mathrm{d}}$ Catalysts were provided by World Gold Council (WGC); ${ }^{\mathrm{H}} \mathrm{H}_{2}$ was replaced by the $\mathrm{N}_{2}$. 
tion-precipitation) DP method supported on the ZnAl-HT were prepared to make a comparison. The catalyst was denoted as the Au/ZnAl-300(DP). As shown in Table 1 entry 4, the performance of the $\mathrm{Au} / \mathrm{ZnAl}-300(\mathrm{DP})$ catalyst was inferior to that of the $\mathrm{Au}_{25} / \mathrm{ZnAl}-300$ catalyst, with the conversion and selectivity decreased from $98.3 \%$ to $61.5 \%$ and from $95.4 \%$ to $85.9 \%$, respectively. Furthermore, the $\mathrm{Au} / \mathrm{ZrO}_{2}, \mathrm{Au} / \mathrm{Fe}_{2} \mathrm{O}_{3}$ and $\mathrm{Au} / \mathrm{TiO}_{2}$ catalysts purchased from Haruta Gold Incorporated Company and World Gold Council were also applied in this reaction for comparison. To be noted, these results were also not as good as that on the $\mathrm{Au}_{25} / \mathrm{ZnAl}-300$ catalyst. As shown in Table 1 , entry $5-7$, the conversions of CAL under the same reaction conditions over the $\mathrm{Au} / \mathrm{ZrO}_{2}, \mathrm{Au} / \mathrm{Fe}_{2} \mathrm{O}_{3}$ and $\mathrm{Au} / \mathrm{TiO}_{2}$ catalysts were $75.7 \%, 93 \%$ and $51.9 \%$, respectively. The corresponding selectivity of COL was $50.0 \%, 45.4 \%$ and $14.6 \%$, respectively, which fell far below that of our $\mathrm{Au}_{25} / \mathrm{ZnAl}-300$ catalyst.

The above results suggested that different supports and the gold precursor would lead to distinctive performances. Thus, the $\mathrm{ZnAl}-\mathrm{HT}$ supported $\mathrm{Au}_{25} \mathrm{NCs}$ as the precatalyst was active and selective for producing of COL from CAL. However, the uncalcined $\mathrm{Au}_{25} / \mathrm{ZnAl}-\mathrm{HT}$ sample was much less active than the heat-treated sample (Table 1, entry 8), in which the conversion of CAL was five times lower than that on the Au25/ZnAl-300 catalyst. The reason might be attributed to the inhibition of substrates by the thiol ligands on the surface [25]. In fact, the thiol ligands were considered as a double-edged sword. On one hand, the thiol ligands maintained the structural integrity of $\mathrm{Au}_{25}$ nanocluster, on the other hand, it disabled the gold sites from adsorbing the reactants. Thus, the intact catalyst was not active for hydrogenation of CAL. To remove the partial thiol ligands through the heat treatment, the active sites were exposed and the reactants could be adsorbed and activated. Besides, previous analysis indicated that the isopropanol solvent might produce the hydrogen in the reaction process [27], which could contribute for the hydrogenation reaction. So, the experiment was conducted on blank ZnAl-HT, which calcined at $300{ }^{\circ} \mathrm{C}$ before the catalytic test (Table 1 , entry 9). It can be found that the conversion of CAL on $\mathrm{ZnAl}-300$ support was only 9.6\%, which was much lower than that on the $\mathrm{Au}_{25} / \mathrm{ZnAl}-300$ catalyst. It implied that the gold particles on the ZnAl-300 support played the major role in dissociating the hydrogen. What's more, as the $\mathrm{H}_{2}$ was replaced by the $\mathrm{N}_{2}$, the conversion of CAL was just $28.4 \%$, which further proved the source of hydrogen was derived from the dissociated hydrogen species stem from gold.

To study the products distribution of the reaction, we conducted the dynamic test of CAL to COL as a function of time over the $\mathrm{Au}_{25} / \mathrm{ZnAl}-300$ catalyst. As seen from the Fig. 4, initially, the desired product (COL) behaved a linear increase with the sacrifice of CAL, which implied a first order reaction happened at this stage. After about one hour, the transformation rate slowed down as the product concentration increased sharply. It meant the conversion of CAL might be hindered by the high concentration of COL. Then, about five hours later, the CAL was almost converted completely, and the selectivity of COL attained $95.4 \%$. At this time, little HCOL appeared as the

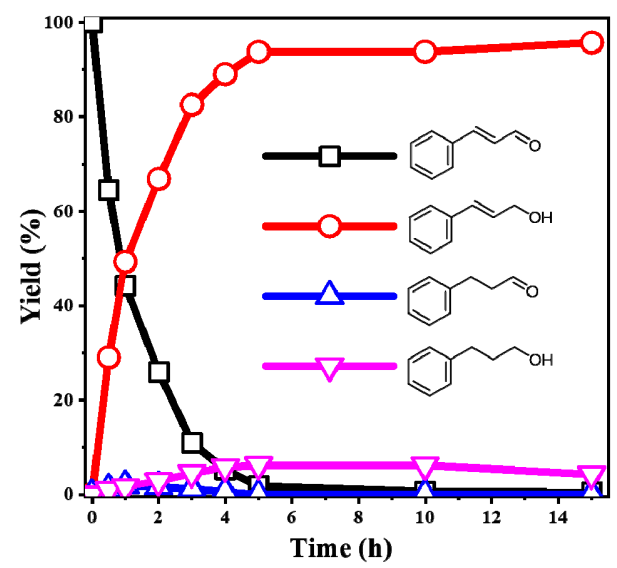

Fig. 4. Time courses of the yield of cinnamaldehyde and cinnamyl alcohol over the $\mathrm{Au}_{25} / \mathrm{ZnAl}-300$ catalyst. Reactions conditions: $130{ }^{\circ} \mathrm{C}, \mathrm{H}_{2} 15$ atm, isopropanol as the solvent, cinnamaldehyde $0.25 \mathrm{mmol}$.

by-product and HCAL could hardly be detected. It was worth noting that the concentration of COL could be maintained at a high level in complete transformation of CAL. Even increasing the reaction time from 5 to $15 \mathrm{~h}$, the yields of the by-products remained below $5 \%$ and the selectivity of COL preserved above $95 \%$. That is, the unsaturated alcohol can be obtained at high and stable selectivity on the Au25/ZnAl-300 catalyst. This phenomenon was quite different with the previous work. Because it is widely accepted that the $\mathrm{C}=\mathrm{C}$ bond and the $\mathrm{C}=\mathrm{O}$ bond are competitively activated on the catalyst $[2,5,19]$. The stable high selectivity at high conversion was also superior to the previously reported gold catalysts [19,30-38], which being compared in Table 2.

\subsection{Discussion about the high selectivity over the Au25/ZnAl-300}

According to the previous literature, the catalytic performances of supported gold catalysts would be strongly dependent on the particle size of gold and the nature of the supports $[39,40]$. In the present work, based on the above results (Table 1), the Au25/ZnAl-300 catalyst exhibited better activity than the $\mathrm{Au} / \mathrm{ZnAl}-300$ (DP) catalyst, which suggested the small gold particles would be beneficial for obtaining the COL from CAL with high conversions, since the supports of both catalysts were the same $\mathrm{ZnAl}-300$. And it can be reasonably concluded that with the decrease in the particle size, the low-coordinated sites such as edges and corners of gold will increase [40]. Thus, it provided more active sites for dissociation of the hydrogen. However, the selectivity of COL in these catalytic systems seems to be largely dependent on the nature of the supports. Because the catalytic performance over different supported gold catalysts were within $5 \mathrm{~nm}$, and the chemical valence of gold on the hydrotalcites supported Au25 NCs didn't show much differences according to our previous work [26]. Thus, the distinctive catalytic performances might be strongly affected by the nature of the support, which could influence the interfacial structure by altering the interaction between gold and the supports or provide the different adsorption sites for the substrates. 
Table 2

Catalytic results reported recently for hydrogenation of CAL to COL over the supported gold catalysts.

\begin{tabular}{|c|c|c|c|c|c|c|c|c|}
\hline \multirow{2}{*}{ Catalyst } & \multicolumn{5}{|c|}{ Reaction conditions } & \multirow{2}{*}{ Conv. $(\%)$} & \multirow{2}{*}{ Sel. (\%) } & \multirow{2}{*}{ Ref. } \\
\hline & Solvent & $\mathrm{Au}(\mathrm{mol} \%)$ & Tem. $\left({ }^{\circ} \mathrm{C}\right)$ & $P_{\mathrm{H} 2}(\mathrm{MPa})$ & $t(\mathrm{~h})$ & & & \\
\hline \multirow{2}{*}{$\mathrm{Au}_{25} / \mathrm{ZnAl}-300$} & \multirow{2}{*}{ isopropanol } & \multirow{2}{*}{1.0} & \multirow{2}{*}{130} & \multirow{2}{*}{1.5} & 5 & 98.3 & 95.4 & \multirow{2}{*}{ This work } \\
\hline & & & & & 15 & 100 & 95.7 & \\
\hline $\mathrm{Au} / \mathrm{ZnO}-\mathrm{CP}$ & isopropanol & 1.0 & 110 & 2 & 0.8 & 100 & $\sim 92$ & [19] \\
\hline $\mathrm{Au} / \mathrm{MgAlO}$ & ethanol & 2.4 & 120 & 1 & 5 & 96 & 40 & [30] \\
\hline $\mathrm{Au} / \mathrm{meso}-\mathrm{CeO}_{2}$ & $\mathrm{H}_{2} \mathrm{O} /$ ethanol & 1.0 & 100 & 1 & 0.5 & 48 & 97 & [31] \\
\hline $\mathrm{Au}_{25} / \mathrm{Fe}_{2} \mathrm{O}_{3}$ & \multirow{2}{*}{ toluene/ethanol } & \multirow{2}{*}{5.1} & \multirow{2}{*}{0} & \multirow{2}{*}{0.1} & \multirow{2}{*}{3} & 49 & 100 & \multirow{2}{*}{ [32] } \\
\hline $\mathrm{Au}_{25} / \mathrm{TiO}_{2}$ & & & & & & 46 & 100 & \\
\hline $\mathrm{Au} / \mathrm{DMF}$ & amide & 1.0 & 60 & 4 & 56 & 94 & 94 & [33] \\
\hline $\mathrm{Au} / \mathrm{Mg}_{2} \mathrm{AlO}$ & ethanol & 0.2 & 120 & 1 & 2 & 78 & 85 & {$[34]$} \\
\hline $\mathrm{Au} / 5 \mathrm{FeAl}$ & \multirow{2}{*}{ isopropanol } & 0.7 & \multirow{2}{*}{100} & \multirow{2}{*}{1} & \multirow{2}{*}{3} & 20 & 67 & \multirow{2}{*}{ [35] } \\
\hline $\mathrm{Au} / \mathrm{HDAE}$ & & 0.6 & & & & 28 & 88 & \\
\hline $\mathrm{Au} / \mathrm{TiO}_{2}$ & ethanol & 6.3 & 60 & 0.1 & - & 50 & 47 & {$[36]$} \\
\hline $\mathrm{Au} / \mathrm{FeOOH}$ & ethanol & 14.8 & 60 & 0.1 & - & 50 & 91 & [37] \\
\hline $\mathrm{Au} / \mathrm{Al}_{2} \mathrm{O}_{3}$ & ethanol & 0.1 & 100 & 8.5 & 2.8 & 94 & 89 & [38] \\
\hline
\end{tabular}

To understand the good performance of the $\mathrm{Au}_{25} / \mathrm{ZnAl}-300$ catalyst and elaborate the specific property for obtaining the desired product (COL) from CAL, the control experiments were implemented under the same conditions on different gold catalysts. Among them, the styrene and/or the artificial mixture of styrene and benzaldehyde were used as the substrates. It has been reported that the acidity or basicity of the support could influence the catalytic performance for the selective hydrogenation reactions. Here, the gold catalysts with supports of different acidity or basicity were chosen. The $\mathrm{Au}_{25} / \mathrm{MgAl}-300$ catalyst with strong basicity [26] and the $\mathrm{Au} / \mathrm{ZrO}_{2}$ catalyst with strong acidity [41] were selected to make a comparison. The results were showed in Table 3. Over the $\mathrm{Au}_{25} / \mathrm{ZnAl}-300$ catalyst, only $3.8 \%-5.1 \%$ of the styrene could be converted with or without the presence of benzaldehyde, while $77.7 \%$ of the benzaldehyde could be transformed to the benzyl alcohol with the presence of the styrene. It indicated that the $\mathrm{Au}_{25} / \mathrm{ZnAl}-300$ catalyst was almost inert for the hydrogenation of the vinyl group but active for the aldehyde group, which led to the high selectivity to the benzyl alcohol. However, over the $\mathrm{Au}_{25} / \mathrm{MgAl}-300$ catalyst, the conversion of styrene was $67.5 \%$ when the styrene was used as the only substrate. Whereas with the existence of benzaldehyde, the conversion of styrene

\section{Table 3}

Control experiments with styrene and benzaldehyde as the substrates over Au catalysts.

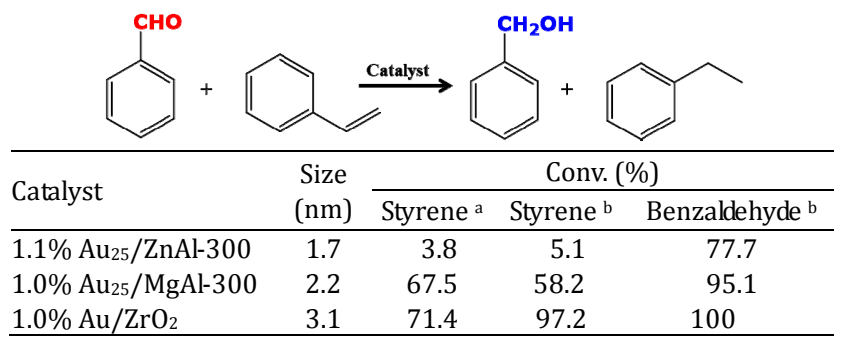

Reactions conditions: $130{ }^{\circ} \mathrm{C}, \mathrm{H}_{2}$ pressure $15 \mathrm{~atm}$, cinnamaldehyde 0.25 mmol, solvent $5 \mathrm{~mL}$ isopropanol, $5 \mathrm{~h}$, catalyst $50 \mathrm{mg}$ (Au $1.0 \mathrm{~mol} \%$ ).

a Substrate $0.25 \mathrm{mmol}$ styrene; b Substrate $0.25 \mathrm{mmol}$ styrene and 0.25 mmol benzaldehyde. decreased to $58.2 \%$. At the same time, the conversion of benzaldehyde was $95.1 \%$. The results suggested that the aldehyde group and the vinyl group were competitively hydrogenated on the $\mathrm{Au}_{25} / \mathrm{MgAl}-300$, and the $\mathrm{C}=0$ bond were preferentially adsorbed on the catalyst instead of the $\mathrm{C}=\mathrm{C}$ bond. Over the $\mathrm{Au} / \mathrm{ZrO}_{2}$ catalyst, the situation was different. When the styrene and the benzaldehyde presented at the same time, both of the two substrates could be converted to the corresponding hydrogenated products with high conversion. Furthermore, the conversion of styrene was even higher than that of the single substrate presented. That meant the presence of aldehyde group might promote the hydrogenation of vinyl group on the $\mathrm{Au} / \mathrm{ZrO}_{2}$ catalyst. From the results, the Au25/ZnAl-300 catalyst with moderate basicity and acidity $[26,42]$ showed the highest selectivity, which indicated the typical basic or acidic supports might be detrimental to the selectivity for the hydrogenation of CAL to COL in this work.

In order to further study the effect of the support on the adsorption and reaction of the substrates, the in-situ DRIFTS of CAL was measured. As indicated in Fig. 5, the substrate could be adsorbed on the surface of the three different catalysts, which could be evidenced by the shift $\left(18-22 \mathrm{~cm}^{-1}\right)$ with that of the liquid substrate $\left(1670 \mathrm{~cm}^{-1}\right)$. The contributions of the IR bands were listed in Table 4. Notably, when high pressure hydrogen (1.5 MPa) was introduced, the appearance of the peak at $3666 \mathrm{~cm}^{-1}$ over the Au25/NiAl-300 catalyst suggested that the $-\mathrm{OH}$ group was formed (Fig. 6(a)) [43-45]. Meanwhile, at the temperature higher than $90{ }^{\circ} \mathrm{C}$, the absorption band attributed to the -CHO (1688 and $2742 \mathrm{~cm}^{-1}$ ) [43,46-51] and the $-\mathrm{C}=\mathrm{C}\left(1626 \mathrm{~cm}^{-1}\right)$ [44] disappeared. Concomitantly, the bands due to the $-\mathrm{CH}_{2}$ (2931 and $2858 \mathrm{~cm}^{-1}$ ) [43,44,48] appeared, which displayed the CAL was transformed to the HCOL. The intensity of the absorption bands of the $-\mathrm{OH}$ and $-\mathrm{CH}_{2}$ remain high when the temperatures ranged from 120 to $150{ }^{\circ} \mathrm{C}$, which reflected the $\mathrm{Au}_{25} / \mathrm{NiAl}-300$ catalyst was not selective for this reaction.

Over the $\mathrm{Au}_{25} / \mathrm{MgAl}-300$ catalyst, similar phenomena were happened: the intensity of the vibration band ascribed to the 


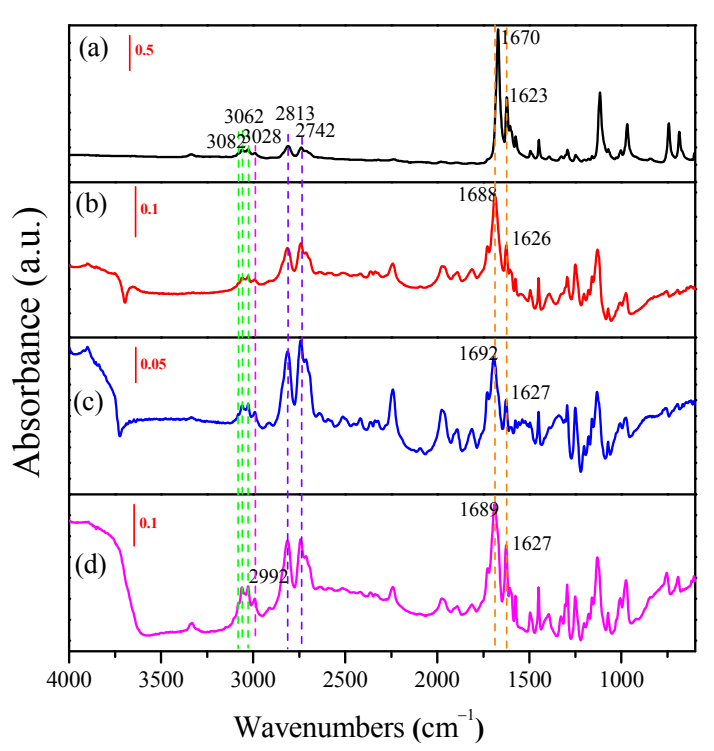

Fig. 5. ATR-IR spectra of the liquid cinnamyl aldehyde (a) and in-situ DRIFTS of the adsorbed CAL over the catalysts: (b) $\mathrm{Au}_{25} / \mathrm{NiAl}-300$; (c) $\mathrm{Au}_{25} / \mathrm{MgAl}-300$; (d) $\mathrm{Au}_{25} / \mathrm{ZnAl}-300$ at $25^{\circ} \mathrm{C}$.

$-\mathrm{CH}_{2}[43,44,48]$ increased with the decrease of that of the $\mathrm{C}=\mathrm{C}$ $\left(1628 \mathrm{~cm}^{-1}\right.$ ) [44] (Fig. 6(b)). But it appeared at higher temperature than that over the $\mathrm{Au}_{25} / \mathrm{NiAl}-300$ (120 vs. $150{ }^{\circ} \mathrm{C}$ ). Besides, there were no free $-\mathrm{OH}$ detected on the $\mathrm{Au}_{25} / \mathrm{MgAl}-300$ catalyst as evidenced by the absence of the absorption band at $3666 \mathrm{~cm}^{-1}$, although the vibrational band of $\mathrm{C}=0$ decreased with the rising temperature. This result indicated that the $\mathrm{Au}_{25} / \mathrm{MgAl}-300$ catalyst was less active than the $\mathrm{Au}_{25} / \mathrm{NiAl}-300$ catalyst.

However, the situation over the $\mathrm{Au}_{25} / \mathrm{ZnAl}-300$ catalyst was completely different from the other two catalysts: all of the peaks ascribed to the $\mathrm{C}=\mathrm{O}$ bond [47-51], the $\mathrm{C}=\mathrm{C}$ bond [44] and the $-\mathrm{CH}$ asymmetric and symmetrical stretching vibration $[43,46,48]$ in aldehyde decreased simultaneously with the increase of the temperature (Fig. 6(c)), while there were no new signal appeared at 3666, 2928 or $2856 \mathrm{~cm}^{-1}$, such results suggested that the adsorption of COL or other intermediate products were very weak and they were probably easily desorbed from the surface of the Au25/ZnAl-300 catalyst. That might be the reason of high selectivity of cinnamyl alcohol on the $\mathrm{Au}_{25} / \mathrm{ZnAl}-300$ catalyst.

To further clarify the high selectivity of COL from CAL over the $\mathrm{Au}_{25} / \mathrm{ZnAl}-300$ catalyst, the ${ }^{27} \mathrm{Al}$ solid-state magic-angle spinning (MAS) nuclear magnetic resonance (NMR) experiments were conducted to provide some evidences. In the ${ }^{27} \mathrm{Al}$ MAS-NMR spectroscopy (Fig. 7), there were two characteristic peaks in ZnAl-HT and MgAl-HT supported $\mathrm{Au}_{25}$ nanoclusters catalysts at around 10 and 72 parts per million (ppm), which represented $\mathrm{Al}^{3+}$ ions in octahedral $\left(\mathrm{Al}_{\mathrm{O}}\right)$ and tetrahedral $\left(\mathrm{Al}_{\mathrm{T}}\right)$ coordination, respectively [55]. Besides, the ${ }^{27} \mathrm{Al}$ MAS-NMR peak at around $47 \mathrm{ppm}$ chemical shift, which could be assigned to $\mathrm{Al}^{3+}$ ions in pentahedral coordination ( $\mathrm{Al} P$ ) [56], only appeared in the $\mathrm{Au}_{25} / \mathrm{ZnAl}-300$ catalyst rather in Au25/MgAl-300 and Au25/ZnAl-200 catalysts. It suggested that the coordinately unsaturated pentacoordinate $\mathrm{Al}^{3+}$ species only existed in $\mathrm{Au}_{25} / \mathrm{ZnAl}-300$, that might supply the oxygen vacancies for the preferential adsorption of the $\mathrm{C}=0$ bond. Thus, the $\mathrm{Au}_{25} / \mathrm{ZnAl}-300$ catalyst exhibited the comparable higher selectivity of COL than the $\mathrm{Au}_{25} / \mathrm{MgAl}-300$ and other supported gold catalysts. The results of oxygen vacancy created by ZnAl-layered hydrotalcite were also agree with the previous literatures $[57,58]$.

Table 4

The attribution of peaks in FTIR spectra of the hydrogenation process of CAL over the $\mathrm{Au}_{25} / \mathrm{NiAl}-300$ catalyst.

\begin{tabular}{|c|c|c|c|c|c|}
\hline Entry & Peak position $\left(\mathrm{cm}^{-1}\right)$ & Group & Intensity & Vibration type & Ref. \\
\hline 1 & 3666 & $-\mathrm{OH}$ & strong & Free $-\mathrm{OH}$ & [43-45] \\
\hline 2 & $\begin{array}{l}3082 \\
3061\end{array}$ & & weak & -CH stretching vibration in aromatic or olefin & {$[43,49]$} \\
\hline 3 & 3025 & & weak & -CH stretching vibration in benzene ring & {$[43,46]$} \\
\hline 4 & $\begin{array}{l}2928 \\
2856\end{array}$ & $-\mathrm{CH}_{2}$ & strong & $\begin{array}{c}-\mathrm{CH} \text { asymmetric and symmetrical stretching vibration in } \\
\text { saturated alkane }\end{array}$ & {$[43,44,48]$} \\
\hline 5 & $\begin{array}{l}2812 \\
2741\end{array}$ & $-\mathrm{CHO}$ & strong & $\begin{array}{c}\text { - } \mathrm{CH} \text { asymmetric and symmetrical stretching vibration in } \\
\text { aldehyde }\end{array}$ & {$[43,46,48]$} \\
\hline 6 & 1688 & $\mathrm{C}=0$ & strong & $\mathrm{C}=0$ stretching vibration in unsaturated aldehyde & [47-51] \\
\hline 7 & $\begin{array}{l}1626 \\
1604\end{array}$ & $\mathrm{C}=\mathrm{C}$ & medium & $\mathrm{C}=\mathrm{C}$ stretching vibration in conjugate alkene & {$[44]$} \\
\hline 8 & $\begin{array}{l}1576 \\
1494\end{array}$ & & weak & skeleton stretching vibration in benzene ring & {$[52,53]$} \\
\hline 9 & $\begin{array}{l}1452 \\
1392\end{array}$ & & weak & $\begin{array}{c}-\mathrm{CH} \text { asymmetric and symmetrical bending vibration in } \\
\text { olefin }\end{array}$ & [53] \\
\hline 10 & $\begin{array}{l}1293 \\
1250\end{array}$ & $=\mathrm{CH}-$ & weak & -CH in-plane bending vibration in olefin & [53] \\
\hline 11 & 1072 & & weak & - $\mathrm{CH}$ in-plane bending vibration in benzene ring & {$[43,46]$} \\
\hline 12 & 976 & $=\mathrm{CH}-$ & weak & -CH out-of-plane bending vibration in olefin & {$[52,54]$} \\
\hline
\end{tabular}



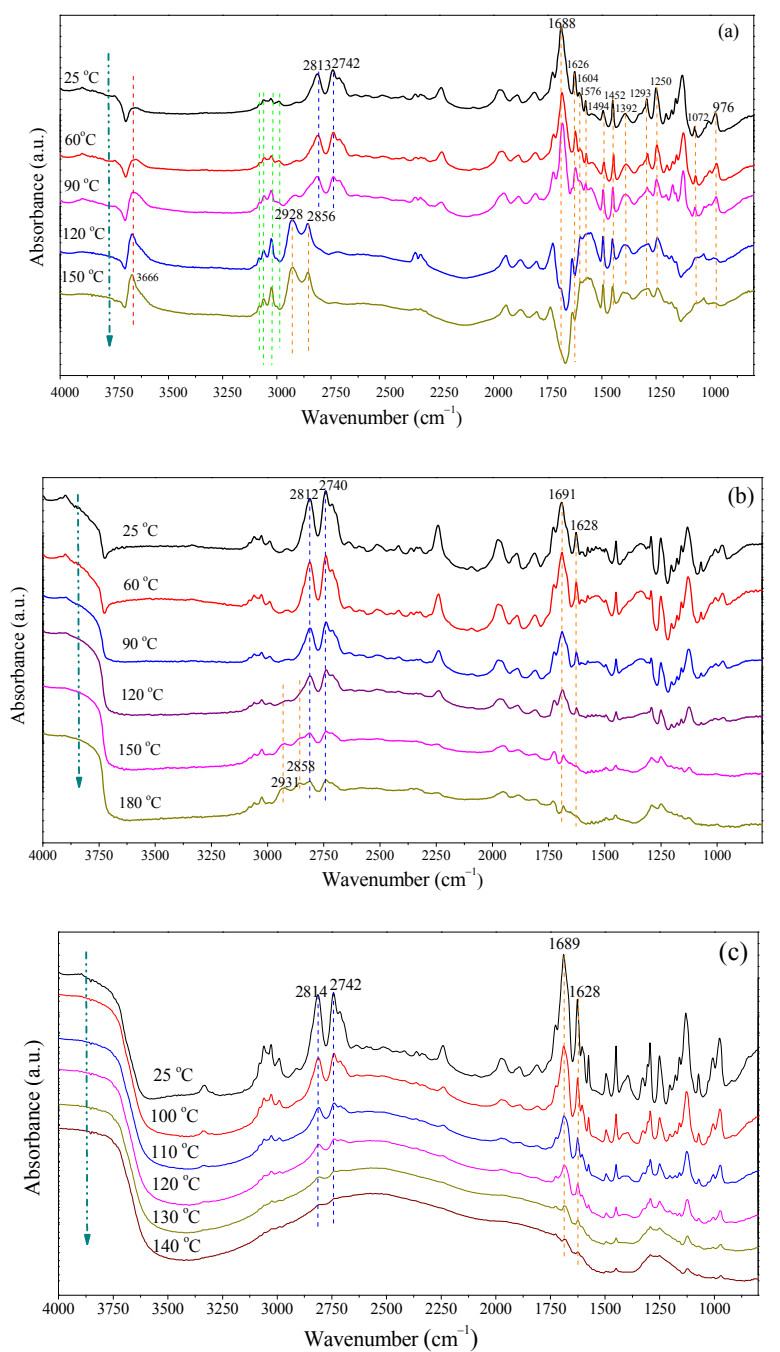

Fig. 6. In-situ DRIFTS of the hydrogenation process of CAL with increasing temperature after introducing $1.5 \mathrm{MPa}$ of hydrogen over the catalysts of $\mathrm{Au}_{25} / \mathrm{NiAl}-300$ (a), $\mathrm{Au}_{25} / \mathrm{MgAl}-300$ (b), and $\mathrm{Au}_{25} / \mathrm{ZnAl}-300$ (c).

\subsection{The active sites and reaction mechanism}

For the hydrogenation of $\alpha, \beta$-unsaturated ketones and aldehydes, it is widely accepted that the reaction pathway occurs via the Horiuti-Polyani mechanism through the adsorbed species of di- $\sigma_{C}=0 \eta^{2}$, di $-\sigma_{c}=c \eta^{2}$ and di- $\pi \eta^{2}\left(\eta^{4}\right)[1,2]$. The key factor that governs the selectivity was generally considered to be the chemisorption modes of the substrate. For example, the catalysts with poor capability for adsorption of the di- $\sigma_{C=C} \eta^{2}$ and/or di- $\pi \eta^{2}\left(\eta^{4}\right)$ would result in the high selectivity of the unsaturated alcohol [1,5]. Previously, Yang et al [24] conducted the theoretical calculations on the adsorption of crotonaldehyde on the $\mathrm{Pt}_{19}, \mathrm{Au}_{19}$, and $\mathrm{Ag}_{19}$ clusters. They found that the di- $\sigma_{\mathrm{C}=\mathrm{C}} \eta^{2}$ and di- $\pi \eta^{2}\left(\eta^{4}\right)$ adsorption modes coexisted on the Pt surface. Thus, both of the $\mathrm{C}=\mathrm{C}$ bond and the $\mathrm{C}=\mathrm{O}$ bond were activated on $\mathrm{Pt}$ surface simultaneously. Therefore, the selectivity of crotonyl alcohol on Pt catalyst was very poor. On the contrary, the $\mathrm{C}=\mathrm{C}$ activation was very weak on $\mathrm{Ag}$ catalysts because of the low adsorption energy in comparison with the activation of the $\mathrm{C}=0$ bond. Besides, a unique atop adsorption mode of $\mathrm{C}=\mathrm{O}$ group were favored on silver atoms. Thus, it led to a high selectivity towards unsaturated alcohol over the Ag catalyst. The situation on $\mathrm{Au}$ catalyst was different, whose performance was highly dependent on the nature of the supports [16,39]. As illustrated in Yang's work, the gold particles loaded on silica exhibited poor selectivity to unsaturated alcohol. But on some reductive supports, the gold catalysts displayed an enhanced selectivity, such as the $\mathrm{Au} / \mathrm{TiO}_{2}[17,36], \mathrm{Au} / \mathrm{CeO}_{2}[31]$ and $\mathrm{Au} / \mathrm{ZnO}[19,22]$ catalysts. That is, the structure of gold could be modified by interacting with the support. Thus, a high density of charge on gold surface might decrease the binding energy of the $\mathrm{C}=\mathrm{C}$ bond by increasing the repulsive four-electron interaction $[59,60]$.

For our Au25/ZnAl-300 catalyst, the gold nanoclusters had a strong interaction with the ZnAl-HT supports by epitaxial interaction and the Au-S-Zn bond at the interfaces, as we proved previously [25]. Then, the geometry and electronic structure of the catalyst could be regulated and optimized for this reaction. What's more, the $\mathrm{Au}_{25} / \mathrm{ZnAl}-300$ catalyst with moderate basicity [26] could get an increased selectivity of COL, which might be caused by the positive effect of bases towards the activation of the $\mathrm{C}=\mathrm{O}$ bond by means of their lone electron pair interacted with the metal surface [2]. Thus, the hydrogenation of the $\mathrm{C}=\mathrm{C}$ bond was hindered as the hydrogenation of $\mathrm{C}=\mathrm{O}$ bond was preferentially favored.

To evaluate the active sites over the Au25/ZnAl-300 catalyst, the geometric construction and electronic structure of gold particles as well as the interaction between gold and the support were very important. Based on our previous work [25], the thiol ligands on the surface of Au NCs were removed after calcination at $300{ }^{\circ} \mathrm{C}$. The gold atoms on the surface were reduced to metallic state. In this work, we found the uncalcined sample was much less active than the heat-treated sample (Table 1, entry 8), in which the conversion of CAL was five times lower than that on the Au25/ZnAl-300 catalyst. The reason might be attributed to the inhibition of substrates by the thiol ligands on the surface. When the experiment conducted on blank ZnAl-HT support (Table 1, entry 9), the conversion of CAL was much lower than that on the $\mathrm{Au}_{25} / \mathrm{ZnAl}-300$ catalyst,

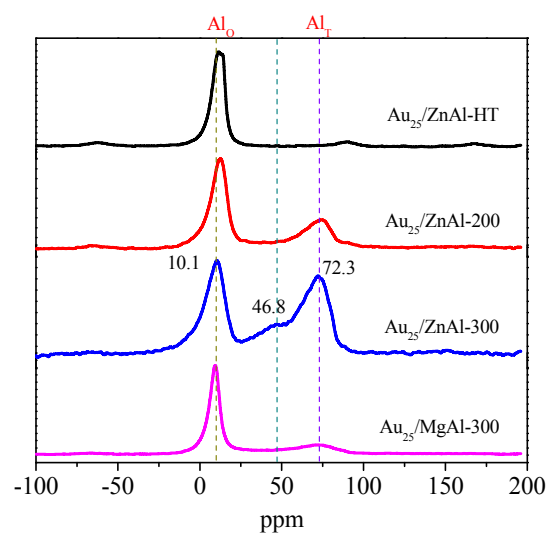

Fig. 7. The ${ }^{27} \mathrm{Al}$ MAS-NMR spectra of supported $\mathrm{Au}_{25}$ nanoclusters catalysts. 


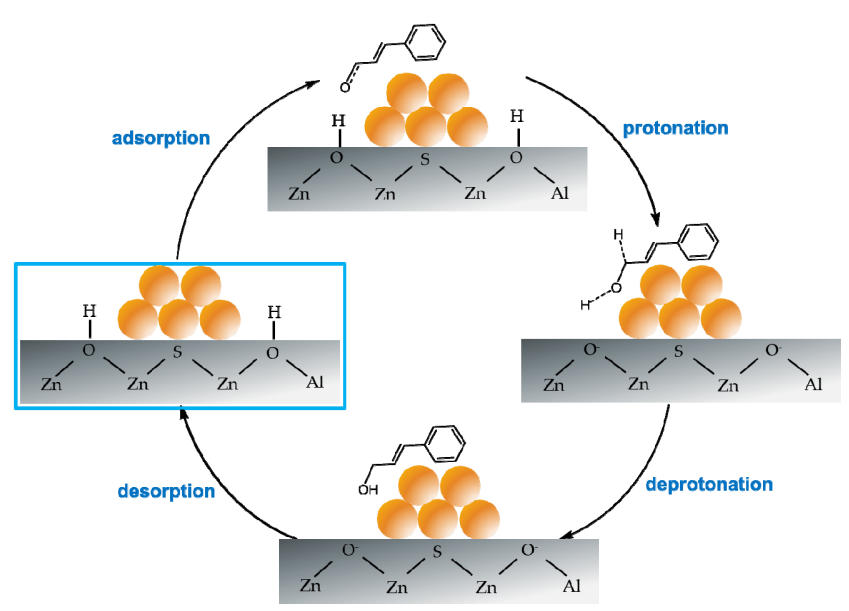

Scheme 2. The proposed mechanism of selective hydrogenation of CAL to COL over the $\mathrm{Au}_{25} / \mathrm{ZnAl}-300$ catalyst.

because the support itself could not dissociate the hydrogen. The protonated hydrogen that partly contributed to the transformation of CAL over the support derived from the decomposition of isopropanol, as the acetone was detected in the products. Nevertheless, when the $\mathrm{H}_{2}$ was replaced by the $\mathrm{N}_{2}$ (Table 1, entry 10), the performance was also far below that on the $\mathrm{Au}_{25} / \mathrm{ZnAl}-300$ catalyst. So, it can be concluded that the hydrogen might be mostly dissociated on the low coordinated gold particles which had low coverage of protective ligands.

What's more, the gold catalysts with different supports exhibited totally different performances (Table 1, entries 2,3,5-7), which suggested the properties of supports were of great importance. The ZnAl-HT appeared to be the best one. Besides, the gold nanoparticles supported on ZnAl-HT and prepared by traditional DP method showed an inferior catalytic performance (Table 1, entry 4) than the thiol stabilized gold

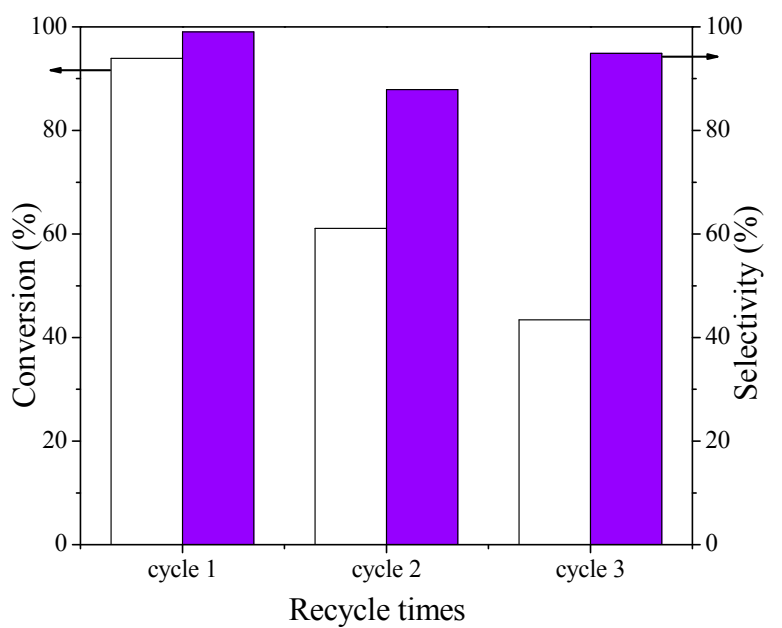

Fig. 8. The conversion of CAL and the selectivity of COL with the recycle times. Reactions conditions: $130{ }^{\circ} \mathrm{C}, \mathrm{H}_{2}$ pressure $15 \mathrm{~atm}$, cinnamaldehyde $0.25 \mathrm{mmol}$, solvent $5 \mathrm{~mL}$ isopropanol, catalyst $50 \mathrm{mg}$. After each test, the catalyst was washed with isopropanol and separated by centrifugation. Then, the new reactant mixture added to the reactor and moved to a next run.

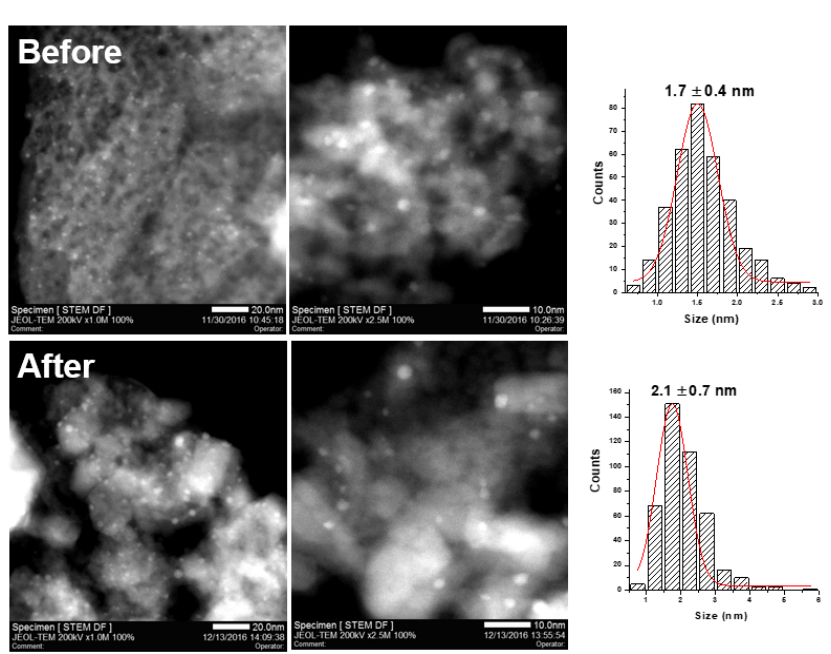

Fig. 9. The HAADF-STEM images of $\mathrm{Au}_{25} / \mathrm{ZnAl}-300$ catalyst before and after using three times in hydrogenation of cinnamaldehyde. Reaction conditions: $130{ }^{\circ} \mathrm{C}, \mathrm{H}_{2}$ pressure $15 \mathrm{~atm}$, cinnamaldehyde $0.25 \mathrm{mmol}$, solvent $5 \mathrm{~mL}$ isopropanol, catalyst $50 \mathrm{mg}$.

(Table 1, entry 1), that indicated the residual sulfur might take a part in the reaction. Furthermore, the oxygen vacancies created by the appearance of the $\mathrm{Al}_{\mathrm{p}}$ might positioned at he gold-support interfaces for the $\mathrm{Au}_{25} / \mathrm{ZnAl}-300$ catalyst, which could preferentially adsorb the $\mathrm{C}=\mathrm{O}$ bond. Based on the above reasons, the key reaction sites that affect the selectivity of COL under the sufficient $\mathrm{H}_{2}$ might be the gold-support interfaces. Further investigation is still needed to make it clear.

A reaction mechanism for the hydrogenation of CAL to COL over the $\mathrm{Au}_{25} / \mathrm{ZnAl}-300$ catalyst was proposed based on the above results (Scheme 2). Firstly, the CAL molecular was absorbed at the interface between gold and the support. During the process, the oxygen vacancy originated from the unsaturated pentacoordinate $\mathrm{Al}^{3+}$ species acted as the Lewis sites and resulted in the preferential adsorption of the $\mathrm{C}=0$ bond $[1,61]$. Then, at the second step, the adsorbed species accepted the hydrogen proton from dissociation of hydrogen on the gold particles and the migration of hydrogen from the solvent to form the intermediate species. With the deprotonation process, the COL was formed on the surface of gold and the support. After desorption, the catalyst was recovered and the next cycle was ready to proceed.

We also conducted the recycle experiments on the $\mathrm{Au}_{25} / \mathrm{ZnAl}-300$ catalyst. The result was showed in Fig. 8. After reusing three times, the conversion of cinnamaldehyde decreased from $94 \%$ to $43 \%$, with the selectivity from $99 \%$ to $95 \%$. We speculated that the deactivation of the catalyst was attributed to the drain of the gold catalysts at the transfer process and the partly agglomeration of the gold particles, because the HAADF-STEM results indicated that the mean particle sizes of gold before and after reusing in hydrogenation of cinnamaldehyde increased from 1.7 to $2.1 \mathrm{~nm}$ (Fig. 9). That might result in the reduction of the catalytic performance. Further characterizations about this are still needed to make it clear. 


\section{Conclusions}

In summary, the ZnAl-hydrotalcite-supported Au25 NCs as the precatalyst was proved very selective for the liquid-phase hydrogenation of CAL to COL. It was active for the hydrogenation of the $\mathrm{C}=\mathrm{O}$ bond but inactive for the activation of the $\mathrm{C}=\mathrm{C}$ bond. Thus, it exhibited a stable high selectivity for unsaturated alcohol even in the prolonged reaction time. The control experiment and in-situ DRIFTS of the substrate under high pressure of hydrogen suggested that the scarce hydrogenation of the vinyl group and the weak adsorption of the products over the Au25/ZnAl-300 catalyst might be responsible for the high selectivity for hydrogenation of carbonyl group. Besides, the ${ }^{27} \mathrm{Al}$ MAS-NMR spectra of $\mathrm{Au}_{25} / \mathrm{ZnAl}-300$ catalyst implied there were coordinately unsaturated Alp species, which might supply the oxygen vacancy for the preferential adsorption of the $\mathrm{C}=0$ bond. The control of the particle size of gold and the choice of ZnAl-HT support as well as the isopropanol solvent determined the good catalytic activity and high selectivity of the target product. We believe this work could provide good references for designing the gold catalysts for chemoselective hydrogenation.

\section{References}

[1] P. Claus, Top. Catal., 1998, 5, 51-62.

[2] P. Gallezot, D. Richard, Catal. Rev. Sci. Eng., 1998, 40, 81-126.

[3] K. Bauer, D. Garbe, H. Surburg, Common Fragrance and Flavor Materials: Preparation, Properties and Uses, 2008.

[4] T. Ohkuma, H. Ooka, T. Ikariya, R. Noyori, J. Am. Chem. Soc., 1995,
$117,10417-10418$.

[5] P. Mäki-Arvela, J. Hájek, T. Salmi, D. Y. Murzin, Appl. Catal. A, 2005, 292, 1-49.

[6] J. M. Grosselin, C. Mercier, G. Allmang, F. Grass, Organometallics, 1991, 10, 2126-2133.

[7] S. J. Chen, L. Meng, B. X. Chen, W. Y. Chen, X. Z. Duan, X. Huang, B. S. Zhang, H. B. Fu, Y. Wan, ACS Catal., 2017, 7, 2074-2087.

[8] M. A. Vannice, B. Sen, J. Catal., 1989, 115, 65-78.

[9] F. Jiang, J. Cai, B. Liu, Y. Xu, X. Liu, RSC Adv., 2016, 6, 75541-75551.

[10] Y. Tan, H. Liu, X. Y. Liu, A. Wang, C. Liu, T. Zhang, Chin. J. Catal,, 2018, 39, 929-936.

[11] H. Wei, X. Wei, X. Yang, G. Yin, A. Wang, X. Liu, Y. Huang, T. Zhang, Chin. J. Catal., 2015, 36, 160-167.

[12] P. Johnston, N. Carthey, G. J. Hutchings, J. Am. Chem. Soc., 2015, 137, 14548-14557.

[13] H. Rojas, G. Diaz, J. J. Martinez, C. Castaneda, A. Gomez-Cortes, J. Arenas-Alatorre, J. Mol. Catal. A, 2012, 363, 122-128.

[14] Z. Konuspayeva, G. Berhault, P. Afanasiev, T. S. Nguyen, S. Giorgio, L. Piccolo, J. Mater. Chem. A, 2017, 5, 17360-17367.

[15] C. H. Hao, X. N. Guo, Y. T. Pan, S. Chen, Z. F. Jiao, H. Yang, X. Y. Guo, J. Am. Chem. Soc., 2016, 138, 9361-9364.

[16] Y. F. Zhang, S. H. Zhang, X. L. Pan, M. Bao, J. H. Huang, W. J. Shen, Catal. Lett., 2017, 147, 102-109.

[17] Y. X. Liu, Y. M. Luo, Z. J. Wei, Asian J. Chem., 2013, 25, 8617-8620.

[18] E. Castillejos, E.Gallegos-Suarez, B. Bachiller-Baeza, R. Bacsa, P. Serp, A. Guerrero-Ruiz, I. Rodriguez-Ramos, Catal. Commun., 2012, 22, 79-82.

[19] H. N. Chen, D. A. Cullen, J. Z. Larese, J. Phys. Chem. C, 2015, 119, 28885-28894.

[20] X. Zhang, Y. C. Guo, Z. C. Zhang, J. S. Gao, C. M. Xu, J. Catal., 2012, 292, 213-226.

[21] G. J. Hutchings, F. King, I. P. Okoye, C. H. Rochester, Appl. Catal. A,

\section{Graphical Abstract}

Chin. J. Catal., 2021, 42: 470-481 doi: 10.1016/S1872-2067(20)63678-6

Producing of cinnamyl alcohol from cinnamaldehyde over supported gold nanocatalyst

Yuan Tan, Xiaoyan Liu*, Leilei Zhang, Fei Liu, Aiqin Wang, Tao Zhang

Dalian Institute of Chemical Physics, Chinese Academy of Sciences; Zhejiang Normal University; University of Chinese Academy of Sciences

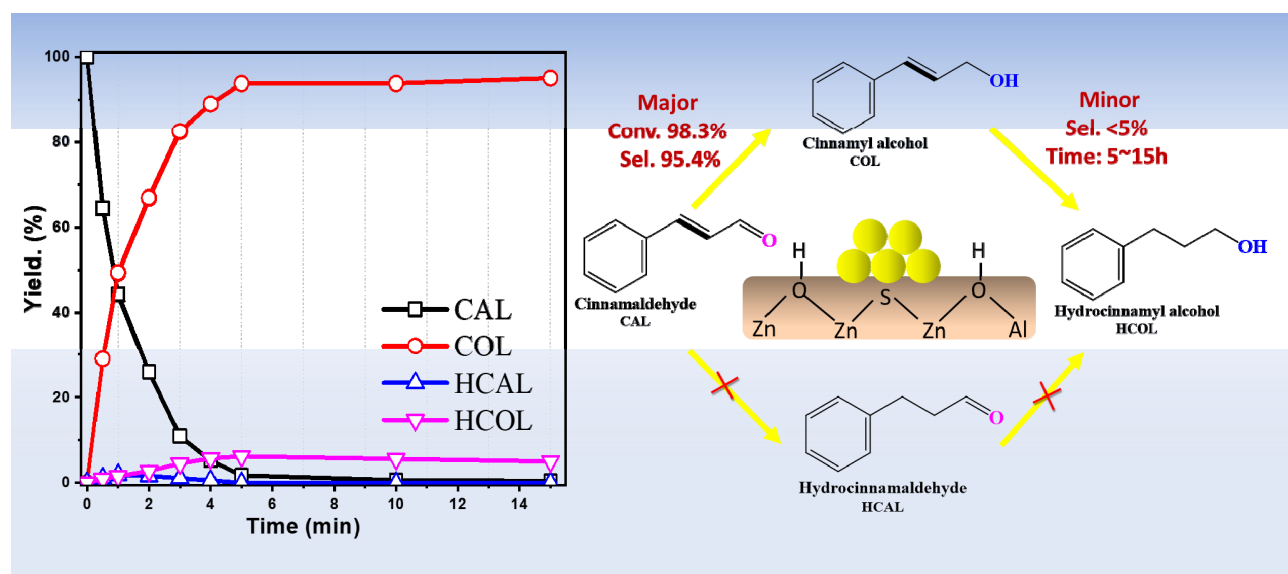

The $\mathrm{Au}_{25} / \mathrm{ZnAl}-300$ catalyst displayed a stable high selectivity to cinnamyl alcohol from the hydrogenation of cinnamaldehyde, which was attributed to the easier adsorption and activation of the $\mathrm{C}=0$ bond than that of the $\mathrm{C}=\mathrm{C}$ bond. 
1992, 83, L7-L13.

[22] J. E. Bailie, G. J. Hutchings. Chem. Commun., 1999, 2151-2152.

[23] J. E. Bailie, H. A. Abdullah, J. A. Anderson, C. H. Rochester, N. V. Richardson, N. Hodge, J. G. Zhang, A. Burrows, C. J. Kiely, G. J. Hutchings, Phys. Chem. Chem. Phys., 2001, 3, 4113-4121.

[24] X. Yang, A. Wang, X. Wang, T. Zhang, K. Han, J. Li, J. Phys. Chem. C, 2009, 113, 20918-20926.

[25] Y. Tan, X. Y. Liu, L. L. Zhang, A. Q. Wang, L. Li, X. L. Pan, S. Miao, M. Haruta, H. S. Wei, H. Wang, F. J. Wang, X. D. Wang, T. Zhang, Angew. Chem. Int. Ed., 2017, 56, 2709-2713.

[26] Y. Tan, X. Y. Liu, L. Li, L. L. Kang, A. Q. Wang, T. Zhang, J. Catal., 2018, 364, 174-182.

[27] H. P. Reddy Kannapu, C. A. Mullen, Y. Elkasabi, A. A. Boateng. Fuel Process. Technol., 2015, 137, 220-228.

[28] D. Wang, C. Deraedt, J. Ruiz, D. Astruc. J. Mol. Catal. A, 2015, 400, 14-21.

[29] H. Lu, H. Yin, Y. Liu, T. Jiang, L. Yu, Catal. Commun., 2008, 10, 313-316.

[30] Z. M. Tian, X. Xiang, L. S. Xie, F. Li, Ind. Eng. Chem. Res., 2013, 52, 288-296.

[31] M. M. Wang, L. He, Y. M. Liu, Y. Cao, H. Y. He, K. N. Fan, Green Chem., 2011, 13, 602-607.

[32] Y. Zhu, H. F. Qian, B. A. Drake, R. C. Jin, Angew. Chem. Int. Ed., 2010, 49, 1295-1298.

[33] P. G. N. Mertens, P. Vandezande, X. Ye, H. Poelman, I. F. J. Vankelecom, D. E. De Vos, Appl. Catal. A, 2009, 355, 176-183.

[34] K. J. You, C. T. Chang, B. J. Liaw, C. T. Huang, Y. Z. Chen, Appl. Catal. A, 2009, 361, 65-71.

[35] J. Lenz, B. C. Campo, M. Alvarez, M. A. Volpe, J. Catal., 2009, 267, $50-56$.

[36] C. Milone, M. C. Trapani, S. Galvagno, Appl. Catal. A, 2008, 337, 163-167.

[37] C. Milone, C. Crisafulli, R. Ingoglia, L. Schipilliti, S. Galvagno, Catal. Today, 2007, 122, 341-351.

[38] E. Bus, R. Prins, J. A. van Bokhoven, Catal. Commun., 2007, 8, 1397-1402.

[39] Sh. K. Shaikhutdinov, R. Meyer, M. Naschitzki, M. Bäumer, H. J. Freund, Catal. Lett., 2003, 86, 211-219.

[40] M. Haruta, Angew. Chem. Int. Ed., 2014, 53, 52-56.
[41] F. Menegazzo, F. Pinna, M. Signoretto, V. Trevisan, F. Boccuzzi, A. Chiorino, M. Manzoli, Appl. Catal. A, 2009, 356, 31-35.

[42] L. Liu, H. Li, Y. Tan, X. Chen, R. Lin, C. Huang, S. Wang, X. Wang, X. Y. Liu, M. Zhao, W. Yang, Y. Ding, Catalysts, 2020, 10, 107.

[43] F. A. Al-Bayati, M. J. Mohammed, Pharm. Biol, 2009, 47, 61-66.

[44] P. Calvini, A. Gorassini, Restaurator, 2002, 23, 48-66.

[45] J. L. Brown, T. Chen, H. D. Embree, G. F. Payne, Ind. Eng. Chem. Res., 2002, 41, 5058-5064.

[46] H. Y. Chen, H. B. Ji, AIChE J., 2010, 56, 466-476.

[47] F. Zhao, S. Fujita, J. Sun, Y. Ikushima, M. Arai, Chem. Commun., 2004, 2326-2327.

[48] H. S. Mansur, C. M. Sadahira, A. N. Souza, A. A. P. Mansur, Mater. Sci. Eng. C, 2008, 28, 539-548.

[49] E. Erasmus, S. Afr. J. Chem., 2013, 66, 216-220.

[50] K. Kervinen, M. Allmendinger, M. Leskelä, T. Repo, B. Rieger, Phys. Chem. Chem. Phys., 2003, 5, 4450-4454.

[51] C. Tengroth, U. Gasslander, F. O. Andersson, S. P. Jacobsson, Pharm. Dev. Technol., 2005, 10, 405-412.

[52] J. N. Xin, Q. Xu, H. Zhang, X. C. Yang, L. H. Lü, Spectrosc. Spect. Anal., 2008, 28, 784-787.

[53] H. Miyata, T. Ohno, F. Hatayama, J. Chem. Soc., Faraday Trans., 1995, 91, 3505-3510.

[54] C. P. Marshall, E. J. Javaux, A. H. Knoll, M. R. Walter, Precambrian Res., 2005, 138, 208-224.

[55] J. Z. Hu, S. Xu, J. H. Kwak, M. Y. Hu, C. Wan, Z. Zhao, J. Szanyi, X. Bao, X. Han, Y. Wang, C. H.F. Peden, J. Catal., 2016, 336, 85-93.

[56] J. H. Kwak, J. Hu, D. Mei, C. W. Yi, D. H. Kim, C. H. F. Peden, L. F. Allard, J. Szanyi, Science, 2009, 325, 1670-1673.

[57] A. A. Ali Ahmed, Z. A. Talib, M. Z. bin Hussein, A. Zakaria, J. Alloys Compd., 2012, 539, 154-160.

[58] Y. Zhao, G. Chen, T. Bian, C. Zhou, G. I. N. Waterhouse, L. Z. Wu, C. H. Tung, L. J. Smith, D. O'Hare, T. Zhang, Adv. Mater., 2015, 27, 7824-7831.

[59] P. Claus, A. Brückner, C. Mohr, H. Hofmeister, J. Am. Chem. Soc., 2000, 122, 11430-11439.

[60] C. Milone, R. Ingoglia, L. Schipilliti, C. Crisafulli, G. Neri, S. Galvagno, J. Catal., 2005, 236, 80-90

[61] G. Li, H. Abroshan, Y. Chen, R. Jin, H. J. Kim, J. Am. Chem. Soc., 2015, 137, 14295-14304.

\title{
纳米金催化肉桂醛选择加氢制肉桂醇
}

\author{
谭 媛, b, 刘晓艳 ${ }^{\mathrm{a},{ }^{*}}$, 张䂞䂞 ${ }^{\mathrm{a}}$, 刘 菲 ${ }^{\mathrm{a}}$, 王爱琴 ${ }^{\mathrm{a}}$, 张 涛, ${ }^{\mathrm{a}, \mathrm{c}}$ \\ a 中国科学院大连化学物理研究所, 中国科学院航天催化材料重点实验室, 辽宁大连116023

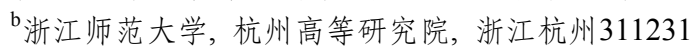 \\ ${ }^{\mathrm{c}}$ 中国科学院大学, 北京 100049
}

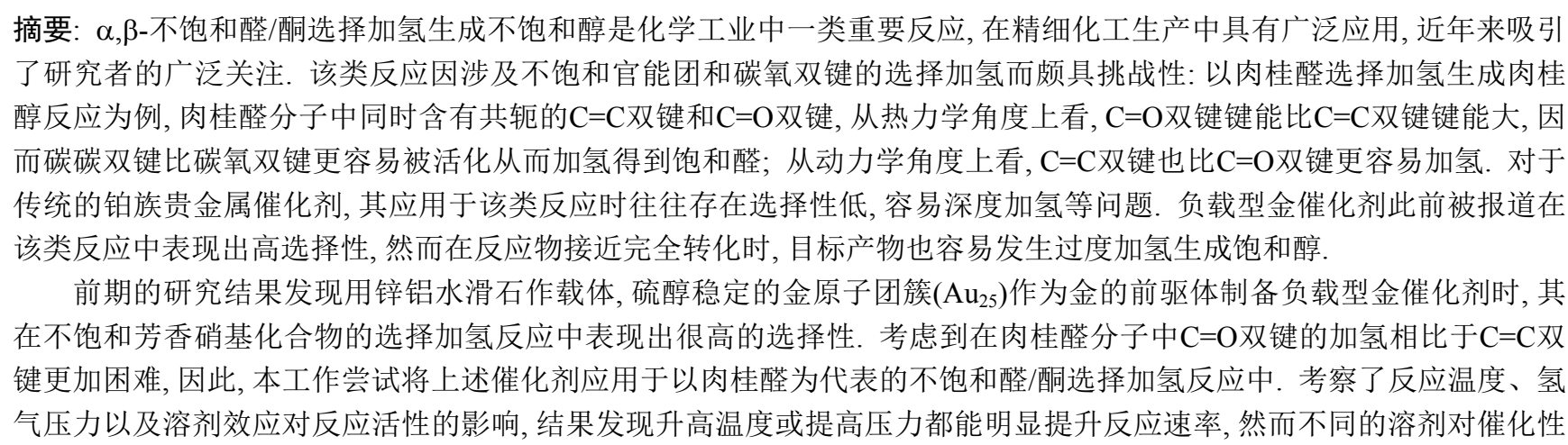


能影响很大, 当以具备氢转移能力的异丙醇和乙醇作为反应溶剂时, 催化活性和选择性最优, 在反应温度为 $130{ }^{\circ} \mathrm{C}$, 氢气压 力为 $15 \mathrm{~atm}$, 异丙醇为溶剂时反应 $5 \mathrm{~h}$, 肉桂醛的转化率和肉桂醇的选择性可以达到 $98.3 \%$ 和 $95.4 \%$, 并且延长反应时间至 15 $\mathrm{h}$, 目标产物也不会发生过度加氢生成苯丙醇, 其选择性可以维持在 $95 \%$ 以上.

为了研究该催化剂高活性和高选择性的原因,制备了不同粒径大小和不同载体负载的金催化剂, 结果发现相比于其它 负载型金催化剂, 以锌铝水滑石负载的 $\mathrm{Au}_{25}$ 团簇作为催化剂前体制得的催化剂在肉桂醛选择加氢制肉桂醇反应中表现出 最优的活性和选择性. 对照实验和原位漫反射红外光谱测试表明上述催化剂对碳碳双键的加氢表现为惰性, 对目标产物 的吸附也相对较弱. ${ }^{27} \mathrm{~A} 1$ 固体核磁共振结果表明配位不饱和的五配位 $\mathrm{Al}_{\mathrm{p}}$ 物种可能为 $\mathrm{C}=\mathrm{O}$ 双键的优先吸附提供所需的氧空 位, 这可能是该催化剂具有较高选择性的原因. 综上, 推测小尺寸的金颗粒具有较多低配位的金原子, 可以活化氢气, 而反 应物和产物的吸脱附性质与载体密切相关, 在以锌铝水滑石为前驱体制备的金催化剂表面, $\mathrm{C}=\mathrm{C}$ 双键吸附较弱, $\mathrm{C}=\mathrm{O}$ 双键 优先吸附, 产物较容易脱附, 不容易发生过度加氢反应, 因此该催化剂在肉桂醛选择加氢反应中表现出高活性和高选择性. 上述工作可以为设计制备高选择性的负载型金催化剂提供参考.

关键词: 金团簇; 载体效应; 肉桂醇; 选择加氢; 肉桂醛

收稿日期: 2020-05-19. 接受日期: 2020-06-23. 出版日期: 2021-03-05.

*通讯联系人. 电话: (0411)84379416; 传真: (0411)84691570; 电子信箱: xyliu2003@dicp.ac.cn

基金来源：国家自然科学基金(21776271，21606227); 国家重点研发计划“纳米科技”重点专项(2016YFA0202801); 中国科学院战 略性先导科技专项(XDB17020100); 浙江省自然科学基金(LQ20B030005); 中国科学院创新交叉团队项目(BK2018001).

本文的电子版全文由Elsevier出版社在ScienceDirect上出版(http://www.sciencedirect.com/science/journal/18722067). 